\title{
The effects of intraruminal infusions of sucrose and xylose on nitrogen and fibre digestion in the rumen and intestines of cattle receiving diets of grass silage and barley
}

\author{
PEKKA HUHTANEN \\ Department of Animal Husbandry, University of Helsinki, \\ SF-00710 Helsinki, Finland
}

\begin{abstract}
Two male cattle (live weight $240 \mathrm{~kg}$ ) fitted with rumen and simple T-piece duodenal cannulas were given a basal diet of $12 \mathrm{~kg}$ of silage $(227 \mathrm{~g} / \mathrm{kg} \mathrm{DM}, 25.7 \mathrm{~g} \mathrm{~N} / \mathrm{kg} \mathrm{DM}), 1 \mathrm{~kg}$ of rolled barley and $100 \mathrm{~g}$ of mineral mixture. In addition to the basal diet, 0, 450 or $900 \mathrm{~g} / \mathrm{d}$ of either sucrose or xylose was continuously infused intraruminally.

The amount of organic matter $(\mathrm{OM})$ entering the duodenum $(\mathrm{P}<0.001)$ and excreted in the faeces $(\mathrm{P}<0.01)$ was linearly increased with the increased sugar infusion. The proportion of digestible OM apparently digested in the rumen averaged 0.694 , and did not differ (P $>0.05$ ) with the level or type of sugar.

Rumen ammonia concentration and molar proportions of isovalerate were decreased $(\mathrm{P}<0.001)$ with increased sugar level. The decrease in the ammonia concentration was slightly less $(\mathrm{P}<0.05)$ with xylose than with sucrose. Molar proportions of acetate, propionate and butyrate were not affected by the sugar level but sucrose produced a lower $(\mathrm{P}<0.05)$ proportion of acetate and higher $(\mathrm{P}<0.01)$ proportion of butyrate than did xylose.

There was a net loss of $\mathrm{N}(11.6 \mathrm{~g} / \mathrm{d})$ between the mouth and duodenum when the basal diet was consumed alone but a net gain $(21.6 \mathrm{~g} / \mathrm{d})$ with the high level of sugar infusion. Microbial $\mathrm{N}$ flow at the duodenum, measured on the basis of RNA purine bases, increased linearly ( $\mathrm{P}<0.001)$ with sugar level. The efficiency of microbial N synthesis $(\mathrm{g} \mathrm{N} / \mathrm{kg} \mathrm{OM}$ apparently digested in the rumen) was 24.0, 29.1 and 30.0 ( $P>0.05$ ) for sugar levels of 0,450 and 900 $\mathrm{g} / \mathrm{d}$, respectively. The amount of microbial $\mathrm{N}$ produced was closely related to rumen ammonia concentration $(r-0.86 ; \mathrm{P}<0.001)$ and outflow of water at the duodenum $(r 0.83 ; \mathrm{P}<0.001)$.

The amounts of neutral detergent fibre (NDF) and acid detergent fibre (ADF) flowing at the duodenum $(\mathrm{P}<0.01 ; \mathrm{P}<0.001)$ and excreted in the faeces $(\mathrm{P}<0.05)$ were increased linearly with sugar level. The increased amounts of fibre digested in the large intestine with sugar infusions were insufficient to compensate for the reduced digestion in the rumen and, as a result, overall digestibilities of NDF and ADF were lower $(\mathrm{P}<0.05)$. The effect of sugar level on the disappearance of silage $\mathrm{N}$-free $\mathrm{OM}$ was consistent with the in vivo digestibility of fibre, although the extent of reduction seemed to be less in nylon bag incubations.
\end{abstract}

Index words: sucrose, xylose, silage, microbial synthesis, digestion 


\section{Introduction}

The change that occurs in nitrogenous components of grass during ensiling is often extensive and varies with the type of fermentation that occurs (McDONALD 1982). Depending on the method of silage making, a substantial proportion of the silage nitrogen $(\mathrm{N})$ may be present as non-protein nitrogenous constituents (NPN).

The efficiency of microbial protein synthesis in the rumen in animals given silage diets has been reported to be lower than in animals given hay or mixed diets. The Agricultural Research Council (1984) reported a value of $23 \mathrm{~g} \mathrm{~N} / \mathrm{kg}$ organic matter apparently digested in the rumen (OMADR) for the efficiency of microbial protein synthesis for silages as compared to $32 \mathrm{~g} \mathrm{~N}$ for hays and grasses. Тномаs and Chamberlain (1982) adopted a mean value of $25 \mathrm{~N} / \mathrm{kg}$ OMADR for silage diets. The reason for the low efficiency of microbial synthesis is not entirely understood, but in part it may be due to the presence of silage fermentation products and hence to the lower yield of ATP/kg OMADR. Extensively fermented silage may contain up to $150 \mathrm{~g}$ lactic acid/kg dry matter (DM), and together with the volatile fatty acids may account for 0.26 of the metabolizable energy (MILLER 1982). It has been suggested that one reason for low efficiency of microbial synthesis is poorly matched rates of ammonia and energy release from silage. However, Тномаs and Тномаs (1985) concluded that with extensively fermented silage the effect is mediated via energy supply rather than proteolysis per se. Reducing the proportion of NAN in silage from 0.56 to 0.40 by increasing the application of formic acid from 0 to 5.9 litres/t had little influence on rumen ammonia concentration, bacterial $\mathrm{N}$ synthesis or passage of undegraded dietary protein to the small intestine (С $\mathrm{HAM}$ BERLAIN et al. 1982). ROOKE et al. (1985a) suggested that the nature of the nitrogenous substances available to rumen microbes may limit the efficiency of microbial synthesis with silage diets.
The different rates of energy and protein release suggest that silages should be supplemented with readily fermentable carbohydrates to promote microbial protein production. No significant improvements in the efficiency of microbial protein synthesis have been found when barley supplements have been given (Thомas et al. 1980a; Rooke et al. 1985a). N retention has frequently been improved with barley supplements (ThOMSON 1968; Kelly and Thомаs 1978), but this effect was not noted by KAISER et al. (1983) for maize starch. The effect of barley and of starch supplements on rumen ammonia concentration has been varied and sometimes no reduction has been found (SyrJäLÄ 1972; THOMAS et al., 1980a; KAISER et al., 1983; CHAMBERLAIN et al. 1985). The benefits of increased energy supply are partly offset by the increased number of protozoa and intraruminal recycling of N (ChAmberlain et al. 1985).

Sugar supplements have been shown to be more effective than starch supplements in reducing rumen ammonia concentration (Syrjälä 1972, Chamberlain et al. 1985), and xylose more effective than sucrose (Chamberlain et al. 1985). Unlike starch, sugars have not increased the rumen protozoal number (Chamberlain et al. 1985).

The purpose of the present study was to quantify the effects of sugar supplements on rumen microbial protein production in cattle given a basal diet of grass silage and barley. To avoid the negative effects of sugar supplements on rumen $\mathrm{pH}$, sugars were given in the form of continuous intraruminal infusions. As another part of the study, it was investigated whether the adverse effect of readily fermentable carbohydrates on rumen cellulolysis could be alleviated by the continuous supply of supplements that would reduce the postprandial change in rumen $\mathrm{pH}$.

\section{Materials and methods}

\section{Animals}

The experimental animals were two Ayrshire male cattle, aged 8 months at the 
time of surgery and weighing $240 \mathrm{~kg}$ at the beginning of the experiment. The animals were fitted with a permanent rumen cannula and a simple T-cannula in the proximal duodenum, approximately $5 \mathrm{~cm}$ posterior to the pylorus and proximal to the point of entry of the common bile duct. The animals were held in metabolism crates. Feed was given in two equal meals at 9 hours and 21 hours. Water was freely available.

\section{Feeds}

The basal diet consisted of $12 \mathrm{~kg}$ of grass silage, $1 \mathrm{~kg}$ of rolled barley $(240 \mathrm{~g} / \mathrm{kg}$ of total dry matter (DM) intake) and $100 \mathrm{~g}$ of commercial mineral mixture. Silage was from second cut timothy, meadow fescue and clover sward, harvested with a precision-chop forage harvester and ensiled with of a solution of formic acid ( $800 \mathrm{~g}$ formic acid/l) at a rate of $5 \mathrm{l} / \mathrm{t}$. The silage was the same as that used in the dairy cow experiment (Huhtanen 1987). Both animals were also infused intraruminally with three different solutions, succesively. The chemical composition of the dietary ingredients is given in Table 1.

\section{Experimental procedure}

The experiment consisted of two periods of 24 days, with each divided into three subperiods of $8 \mathrm{~d}$. Intraruminal infusions of sucrose and xylose were given at three different levels: 0 (control), 450 (low) and 900 (high) $\mathrm{g} / \mathrm{d}$. During the first period animal A was intraruminally infused with water for days $1-8$, with $450 \mathrm{~g}$ of sucrose for days $9-16$ and with $900 \mathrm{~g}$ of sucrose for days $17-24$. At the same time animal B was infused with water, $450 \mathrm{~g}$ of xylose and $900 \mathrm{~g}$ of xylose, successively. In the second period the infusions of the animals were reversed. After the first period about $10 \mathrm{~kg}$ of rumen contents from a bull given a similar basal diet was transferred into the rumen of each animal to hasten the adaptation to the new diet. The animals were then given a rest period of $5 \mathrm{~d}$ before the second period commenced. The sugars was infused at a rate of $75 \mathrm{ml} / \mathrm{h}$ with a peristaltic pump (Watson-Marlow Ltd, Cornwall).

$\mathrm{Cr}$-labelled straw was used as particulate marker and CoEDTA as liquid phase marker. Markers were prepared as described by UDÉN et al. (1980). Fifteen grammes $(2 \times 7.5 \mathrm{~g})$ of $\mathrm{Cr}$-straw $(68 \mathrm{mg} \mathrm{Cr} / \mathrm{g}$ ) per day was administrated via rumen cannula at feeding times and 4 grammes of CoEDTA per day was infused continuously with the nutrient infusates. The amount of constituents excreted in faeces was determined using $\mathrm{Cr}$ as an indigestible marker. Faeces were collected totally on day 8 of each subperiod and mixed thoroughly, and a representative sample was taken.

Duodenal samples (approximately $120 \mathrm{ml}$ ) were taken on day 8 of each subperiod at $2 \mathrm{~h}$ intervals through a $24 \mathrm{~h}$ period and pooled to provide a sample. This sample was further divided into two parts, of which one part was further divided by centrifugation ( $800 \mathrm{~g}$ for $10 \mathrm{~min}$ ) into liquid phase and particulate matter. The unrepresentative digesta sample and the particulate matter were oven-dried at $60{ }^{\circ} \mathrm{C}$, milled and stored before analyses. The liquid phase was stored at $0{ }^{\circ} \mathrm{C}$ before the analysis of markers. Rumen samples were

Table 1. Chemical composition of experimental feeds.

\begin{tabular}{|c|c|c|c|c|c|c|c|c|}
\hline & \multirow[b]{2}{*}{ DM $(\mathrm{g} / \mathrm{kg})$} & \multicolumn{7}{|c|}{ In dry matter $(\mathrm{g} / \mathrm{kg})$} \\
\hline & & Ash & $\mathrm{N}$ & NDF & ADF & $\mathrm{C}$ & $\mathrm{HC}$ & ADL \\
\hline Silage & 227 & 89 & 25.7 & 582 & 346 & 313 & 236 & 33 \\
\hline Barley & 867 & 28 & 19.6 & 228 & 76 & 62 & 152 & 14 \\
\hline
\end{tabular}

$\mathrm{C}=$ cellulose, $\mathrm{HC}=$ hemicellulose, $\mathrm{ADL}=$ acid detergent lignin. In silage: $\mathrm{pH} 4.14 ;$ in $\mathrm{DM}(\mathrm{g} / \mathrm{kg}) ;$ sugars 26 , lactic acid 41 , acetic acid 18, propionic acid 0.3 , butyric acid 0.3 ; in total $\mathrm{N}(\mathrm{g} / \mathrm{kg}): \mathrm{NH}_{3}-\mathrm{N} 50$, soluble $\mathrm{N} 460$. 
taken before feeding and thereafter 1, 2, 3, $4,6,8$ and $10 \mathrm{~h}$ after feeding.

The rate of disappearance of dry matter (DM), organic matter (OM), N-free OM, residual fraction and nitrogen $(\mathrm{N})$ of the silage used in the experiment and of the untreated barley straw was determined in the rumen of both animals for each infusion. The residual fraction was calculated as $\mathrm{OM}$ minus crude protein, sugars and fermentation acids. Fermentation acids and sugars were assumed to be lost in washing and were not determined from the residues. From day 6 to day 8 of each subperiod, bags (porosity $40 \mu \mathrm{m}$ ) containing $3.5 \mathrm{~g}$ of DM were incubated for periods of 12 , 24 and 48 ( 9 bags/feed, 18 bags/animal) and a ' $0 \mathrm{~h}$ wash' value was determined for three bags per feed.

\section{Analytical methods}

Oven DM content of silage was corrected for volatile losses of lactic acid, volatile fatty acids (VFA) and ammonia as described by Porter et al. (1984). Fermentation quality of the silage was analysed by the methods described by HUHTANEN (1987). N content of feeds, digesta samples and faeces was determined by Kjeldahl method. Neutral detergent fibre (NDF), acid detergent fibre (ADF) and acid detergent lignin (ADL) were analysed according to GoERING and VAN SOEST (1970), but as modified by ROBERTSON and VAN SOEST (1977) for barley samples. Hemicellulose was calculated as the difference between NDF and $\mathrm{ADF}$, and cellulose as the difference between $\mathrm{ADF}$ and $\mathrm{ADL}$. In vitro digestibility of silage was determined by the two-stage procedure of TILley and Terry (1963) to control the variation in silage quality during the experiment. The ammonia $\mathrm{N}$ concentration in rumen samples and in the liquid phase of duodenal digesta was determined by the method of Mccullough (1967). VFAs in rumen fluid samples taken before feeding and 2, 4 and $6 \mathrm{~h}$ after feeding were determined by gas liquid chromatography (HuIDA 1973). Purine contents of digesta samples and faeces were determined by the method of ZINN and OwEns (1982). The concentrations of $\mathrm{Cr}$ and Co in digesta and faecal samples were determined by atomic absorption spectrophotometry after ashing of the samples and digestion with a potassium bromate acid mixture (Williams et al. 1962).

\section{Calculation of results}

The flow of digesta DM and other constituents entering the small intestine was calculated by FAICHNEY's (1975) double marker method, with the modification that marker concentrations in the unrepresentative digesta sample and solid phase were used to calculate the reconstitution factor (FrANCE and SIDDONS 1986). The flow of $\mathrm{N}$ in the microbial fraction at the duodenum was calculated by reference to purine in digesta. The value 0.15 for the ratio nucleic acid (RNA-basis) N:total $\mathrm{N}$ in rumen bacteria was used to calculate the flow of microbial N (ZINN and OwENS 1986). Feed $\mathrm{N}$ degradability was calculated as (1 (Total $\mathrm{N}-$ ammonia $\mathrm{N}-$ microbial $\mathrm{N}-$ endogenous N))/Feed N. A value of $130 \mathrm{mg}$ / $\mathrm{kg}^{0.75}$ was used to estimate the flow of endogenous $\mathrm{N}$ into the duodenum (ØRSKOV and MacLEOD 1983). Outflow of water was calculated as total digesta flow minus DM flow.

\section{Statistical analyses}

The statistical model used to analyse the flow data of different constituents was

$y_{i j k l m}=\mu+A_{i}+P_{j}+L_{k}+S_{l}+e_{i j k l m}$

where $A, P, L$ and $S$ are the effects of animal, period, sugar level and sugar. The effect of the sugar level was further partioned into the effect due to linear and quadratic trends (Snedecor and Cochran 1967). A split-plot analysis of variance was fitted to the data from rumen fluid analyses:

$$
\begin{aligned}
y_{i j k l m n} & =\mu+A_{i}+P_{j}+L_{k}+S_{l}+e_{i j k l}+H_{m}+ \\
& (A H)_{i m}+(P H)_{j m}+(L H)_{k m}+(S H)_{l m}+ \\
& e_{i j k l m n}
\end{aligned}
$$




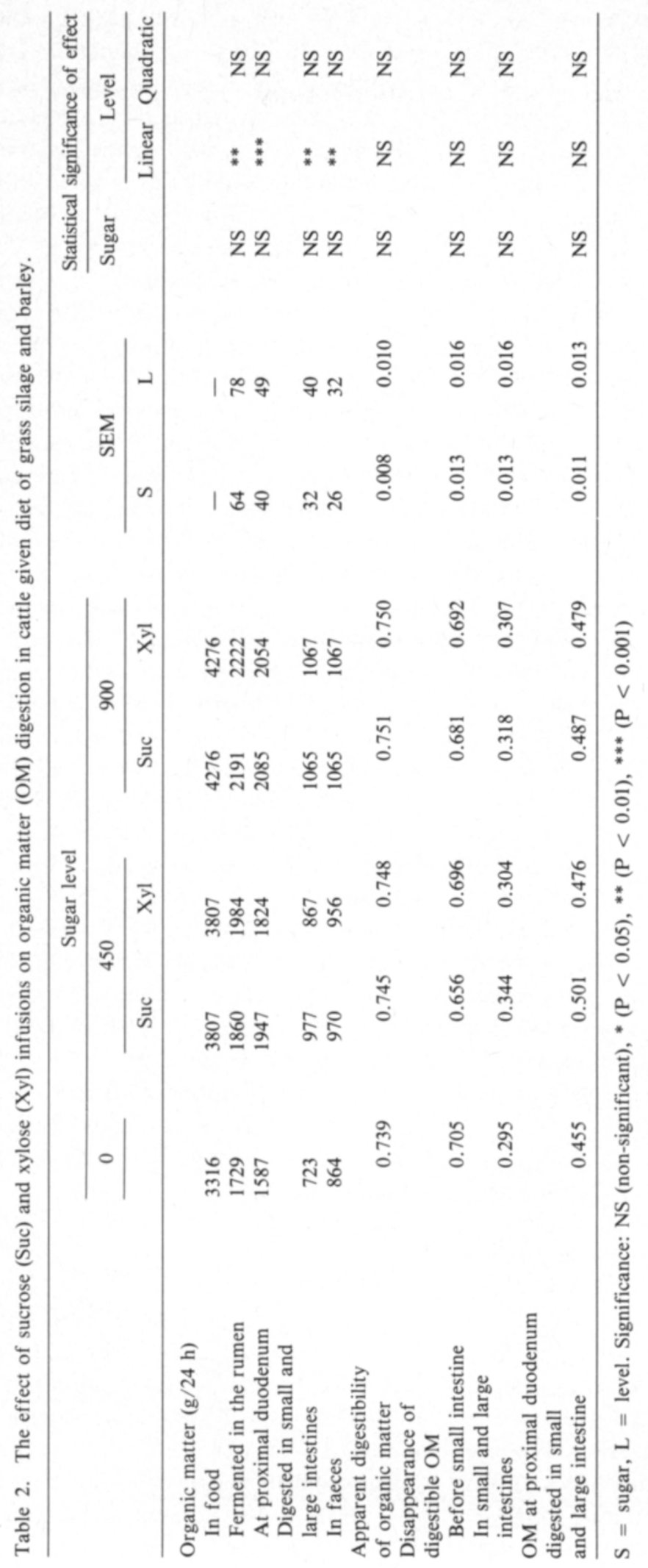


where $A, P, L$ and $S$ are the same effects as in model (1), $e_{i j k l}$ is the main plot error and $H$ is the effect of sampling time.

\section{Results}

\section{Digestion of organic matter}

DM intake of the basal diet was $60 \mathrm{~g} \mathrm{DM} / \mathrm{kg}$ $\mathrm{W}^{0.75}$. The amounts of ingested organic matter (OM) and the amounts of OM measured at the proximal duodenum and in the faeces are shown in Table 2. The amounts of OM entering the proximal duodenum and which were subsequently voided in faeces were linearly increased $(\mathrm{P}<0.001 ; \mathrm{P}<0.01)$ with sugar level. Differences between the sugars in respect of digestion of OM were small and non-significant. The amount of OM apparently digested in the rumen was increased $(\mathrm{P}<$ 0.01 ) with sugar level. There was a tendency for the total OM digestibility to be higher when sugar supplements were given. The average increase in digestible $\mathrm{OM}$ intake was $0.84 \mathrm{~kg} / \mathrm{kg}$ sugar infused.

The proportion of digestible OM disappearing in the rumen averaged 0.694 , and was not affected either by the type or level of sugar. The amount of OM digested in the small and large intestines was linearly $(\mathrm{P}<$ 0.01 ) increased with sugar level. The proportion of $\mathrm{OM}$ entering the duodenum that disappeared in the intestines averaged 0.467, and tended to be higher when sugar supplements were given.

\section{$N$ metabolism}

The average $\mathrm{N}$ concentration in the diet was 24.3, 21.1 and $19.7 \mathrm{~g} / \mathrm{kg}$ DM for infusion levels of 0,450 and $900 \mathrm{~g}$, respectively. There was a linear $(\mathrm{P}<0.01)$ increase in the flow of total $\mathrm{N}$ at the duodenum with sugar level. Ammonia $\mathrm{N}$ flow averaged $3.1 \mathrm{~g} / \mathrm{d}$ and was unaffected by the supplementation. The pattern of flow of non-ammonia N (NAN) was therefore similar to that of total $\mathrm{N}(\mathrm{P}<$ 0.01 ). The flow of microbial $\mathrm{N}$ was linearly
$(\mathrm{P}<0.001)$ increased with sugar level. On the average, microbial $\mathrm{N}$ production was increased by $25 \mathrm{~g} / \mathrm{kg}$ sugar infused. The quantity of $\mathrm{N}$ excreted in faeces was increased with sugar level $(\mathrm{P}<0.01)$ and the resulting fall in apparent digestibility of $\mathrm{N}$ was significant $(\mathrm{P}<0.05)$. On the other hand, $\mathrm{N}$ entering the duodenum was more digestible $(\mathrm{P}<0.05)$ when sugars were infused.

The efficiency of microbial $\mathrm{N}$ synthesis ( $\mathrm{g}$ $\mathrm{N} / \mathrm{kg}$ OM apparently digested in the rumen (OMADr)) averaged $27.8 \mathrm{~g} \mathrm{~N} / \mathrm{kg}$ OMADr, and was not significantly affected either by the level or the type of sugar. When expressed in relation to $\mathrm{OM}$ truly digested in the rumen, by assuming that microbial matter had a $\mathrm{N}$ :OM ratio of 0.09 (CZERKAWSKI 1986), values showed a narrower range with a mean value of 21.2. However, there was a trend toward higher efficiency when sugars were given, and more so for sucrose than xylose. On basal diet there was a substantial loss of $\mathrm{N}$ between the mouth and duodenum, but with sugar infusions the flow of NAN at the duodenum exceeded the amount of $\mathrm{N}$ ingested by $0.07-0.23$. Outflow of water at the duodenum was increased $(\mathrm{P}<0.05)$ with sugar infusions.

The apparent loss of RNA between duodenum and faeces was 0.818 (SE 0.010). Faecal $\mathrm{N}$ loss was closely related to the passage of NAN at the proximal duodenum: (Faecal $\left.\mathrm{N}(\mathrm{g})=0.155^{*} \mathrm{NAN}+10.5 ; r=0.80^{* *}\right)$. Based on this equation, the true digestibility of NAN was 0.845 and metabolic faecal $\mathrm{N}$ $10.5 \mathrm{~g}$, which is equivalent to $2.5 \mathrm{~g} \mathrm{~N} / \mathrm{kg} \mathrm{DM}$ intake.

\section{Digestibility of fibre components}

NDF intake ranged from 1755 to $1799 \mathrm{~g} / \mathrm{d}$ and intake of ADF from 986 to $1011 \mathrm{~g} / \mathrm{d}$ (Table 4). Increasing the amount of sugar infused resulted in a linear increase in the flow of NDF $(\mathrm{P}<0.01)$ and ADF $(\mathrm{P}<0.001)$ at the proximal duodenum and a fall in the quantity of NDF and ADF fermented in the rumen $(\mathrm{P}<0.05, \mathrm{P}<0.01)$. With sugar diets the 


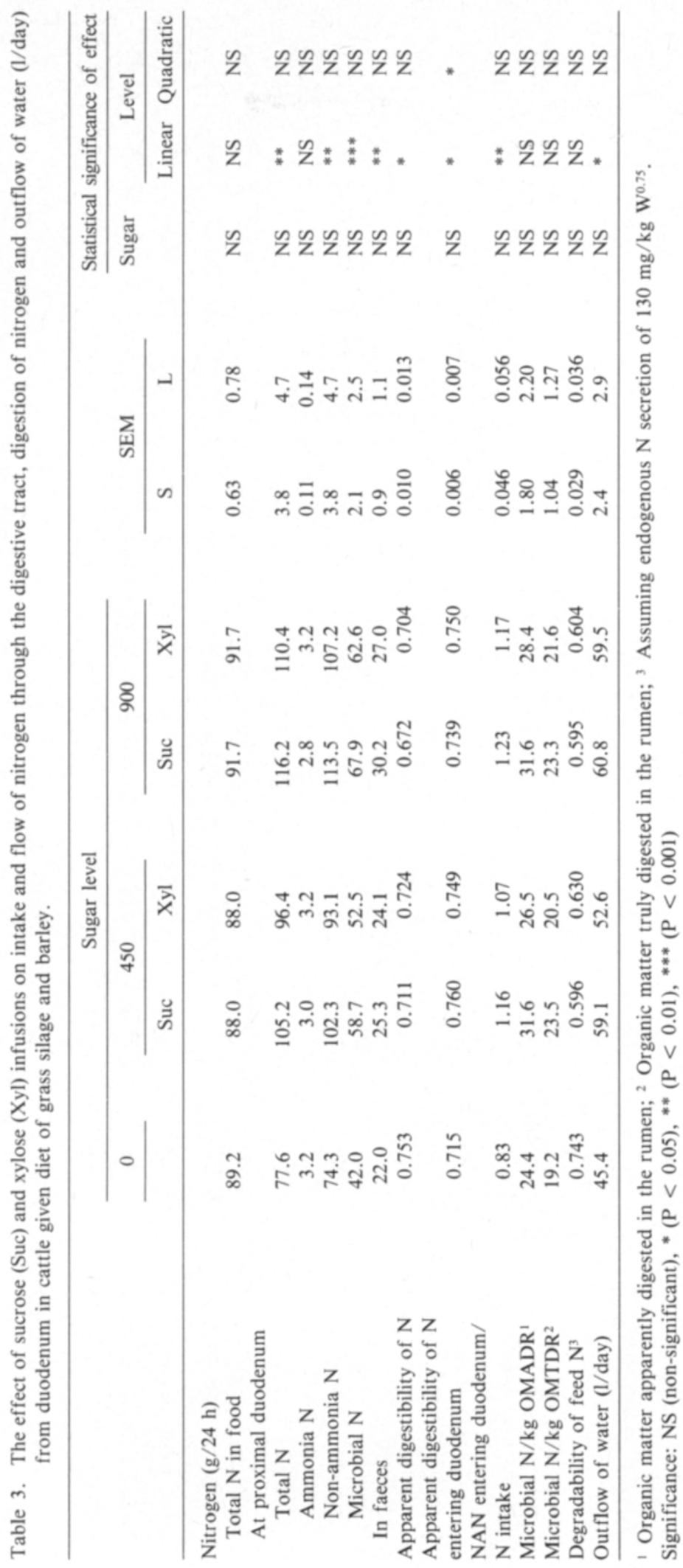




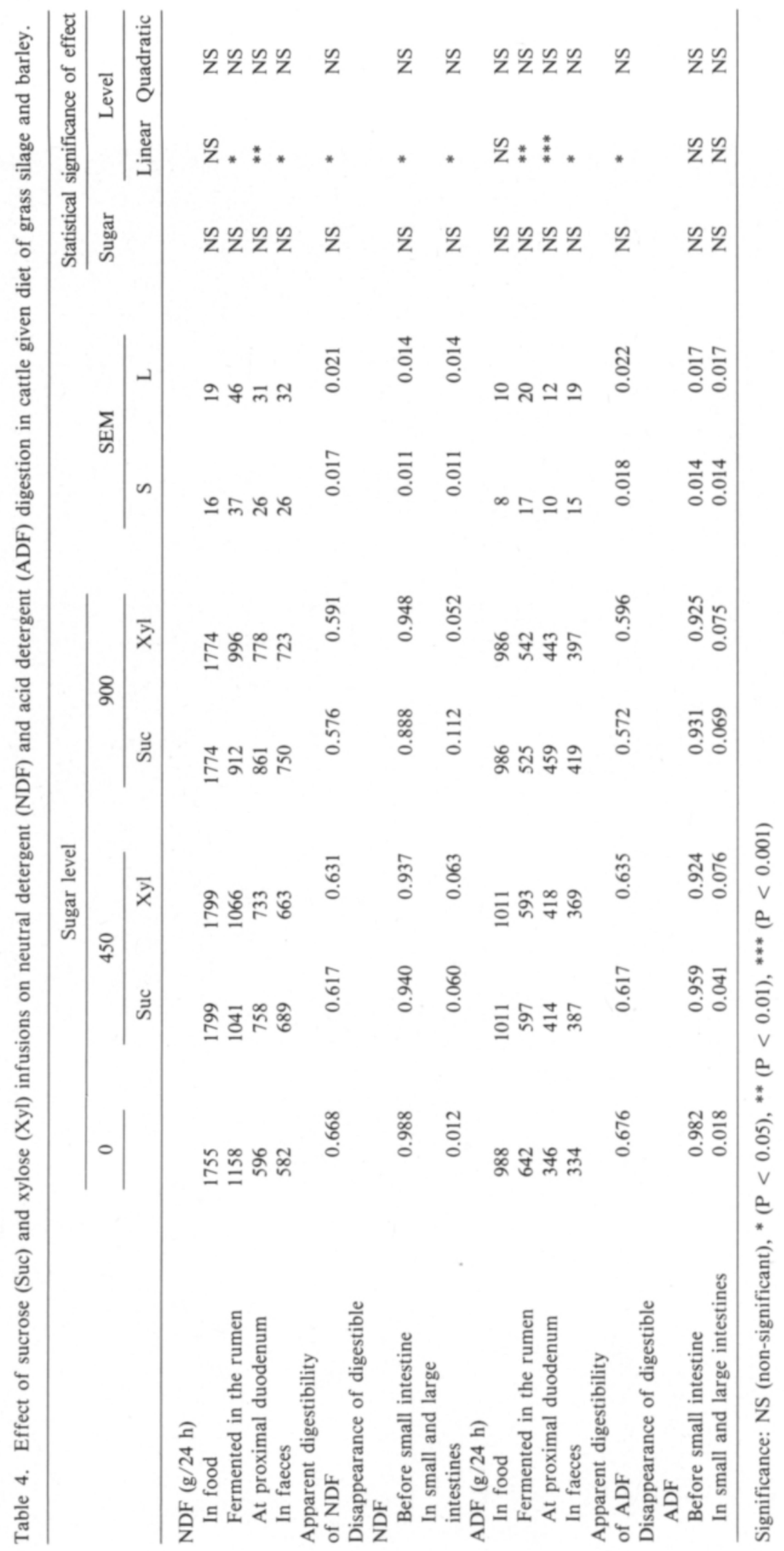




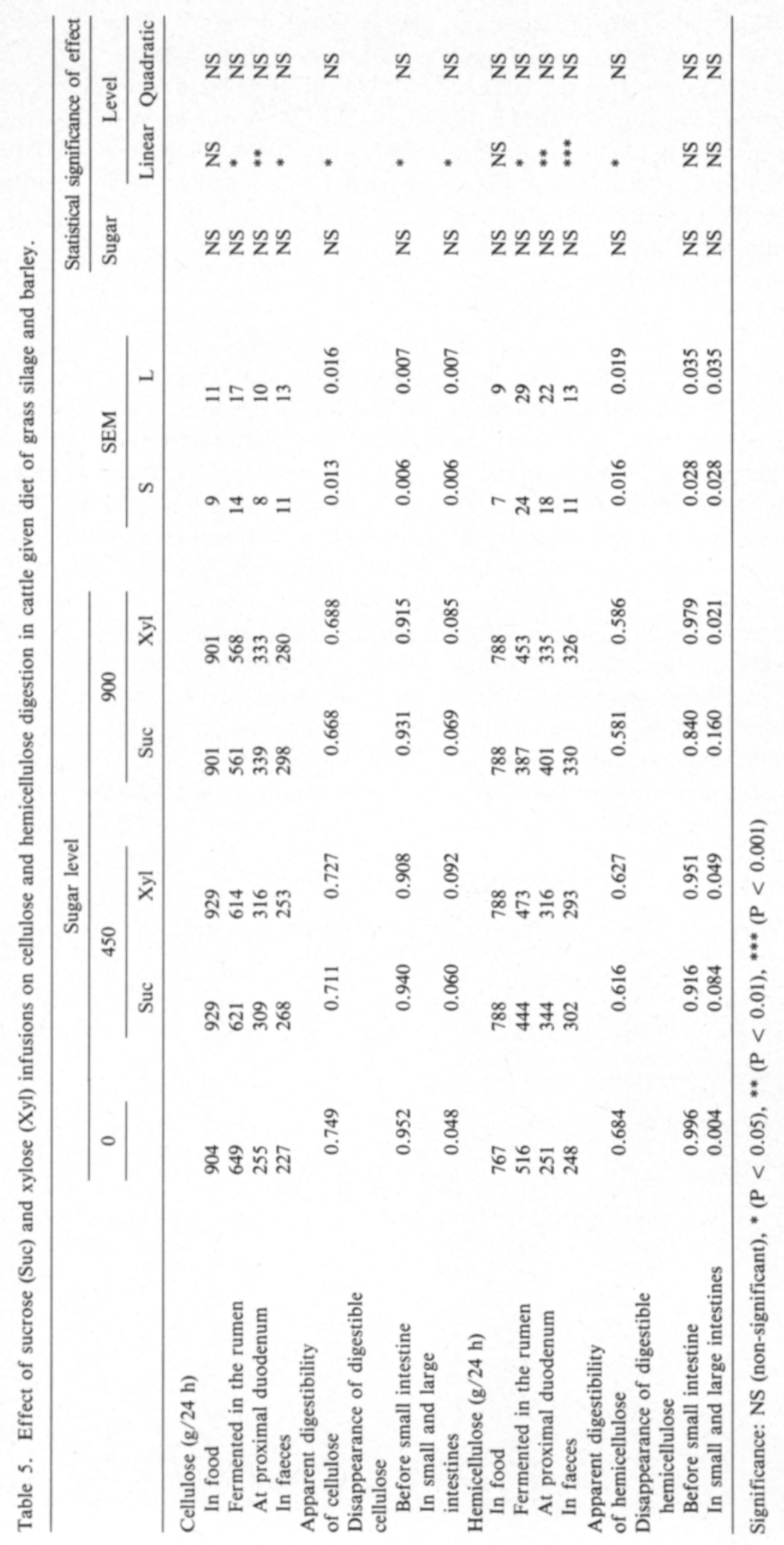


amount of NDF digested postruminally increased from 14 (control) to 70 (low) and $83 \mathrm{~g} / \mathrm{h}$ (high). However, increased NDF and $\mathrm{ADF}$ digestion in the intestines was insufficient to compensate for the reduced fibre digestion in the rumen. There was a linear increase $(\mathrm{P}<0.05)$ in faecal output NDF and ADF with sugar level. Total digestibilities of NDF and ADF were higher $(\mathrm{P}<0.05)$ when the basal diet was given alone than when supplemented with the high level of sugar ( 0.668 vs. $0.584 ; 0.676$ vs. 0.584$)$. With both levels of xylose, NDF and ADF digestibilities were marginally higher than they were with sucrose. The proportion of NDF digestion occurring in the rumen fell linearly $(\mathrm{P}<0.05)$ with sugar level; a similar tendency was found for ADF, but the difference was not significant.

Values for cellulose and hemicellulose digestion indicate similar effects due to the level of sugar infusion as observed for NDF and ADF (Table 5). Increasing the level of sugar decreased the quantities of cellulose and hemicellulose fermented in the rumen, with a consequent linear $(\mathrm{P}<0.05)$ decrease in the overall digestibility of cellulose from 0.749 to 0.678 and of hemicellulose from 0.684 to 0.584 . The proportion of digestible cellulose fermented in the rumen was decreased $(\mathrm{P}<$ 0.05 ) due to the sugar infusions and the same tendency was found for hemicellulose.

\section{Rate of degradation of silage}

Values describing the disappearence of silage constituents from nylon bags incubated in the rumen are presented in Table 6. The disappearance of silage OM, N-free OM and residual fraction was reduced with increased level of sugar infusion, but only after incubation of $48 \mathrm{~h}$ were the linear effects of sugar level significant $(\mathrm{P}<0.01, \mathrm{P}<0.001)$. After an incubation period of $24 \mathrm{~h}$ the difference was close to becoming significant $(\mathrm{P}=0.066)$. Because sugar infusions tended to increase $\mathrm{N}$ loss, the disappearance of $\mathrm{N}$-free $\mathrm{OM}$ was more strongly affected by the sugar infusions than the disappearance of DM or OM. The content of the residual fraction in silage was $667 \mathrm{~g} / \mathrm{kg} \mathrm{DM}$, which is slightly higher than the

Table 6. Effect of sucrose (Suc) and xylose (Xyl) infusions on the disappearance $(\mathrm{mg} / \mathrm{g})$ of different constitutents of silage from nylon bags incubated in the rumen of cattle.

\begin{tabular}{|c|c|c|c|c|c|c|c|c|c|}
\hline & \multicolumn{2}{|c|}{ Sugar } & \multicolumn{3}{|c|}{ Level } & \multicolumn{2}{|c|}{ SEM } & \multirow{2}{*}{\multicolumn{2}{|c|}{$\begin{array}{l}\text { Statistical signifi } \\
\text { cance of effect }\end{array}$}} \\
\hline & \multirow[t]{2}{*}{ Suc } & \multirow[t]{2}{*}{ Xyl } & \multirow[t]{2}{*}{0} & \multirow[t]{2}{*}{450} & \multirow[t]{2}{*}{900} & \multirow[t]{2}{*}{$\mathrm{S}$} & \multirow{2}{*}{ L } & & \\
\hline & & & & & & & & Sugar & Level' \\
\hline \multicolumn{10}{|l|}{$\mathrm{OM}$} \\
\hline $12 \mathrm{~h}$ & 420 & 447 & 460 & 412 & 428 & 15.4 & 18.8 & NS & NS \\
\hline $24 \mathrm{~h}$ & 599 & 603 & 616 & 598 & 587 & 8.9 & 10.9 & NS & NS \\
\hline $48 \mathrm{~h}$ & 699 & 707 & 717 & 701 & 691 & 4.6 & 5.7 & NS & $* *$ \\
\hline \multicolumn{10}{|c|}{ Nitrogen } \\
\hline $12 \mathrm{~h}$ & 741 & 753 & 753 & 730 & 758 & 12.4 & 15.2 & NS & NS \\
\hline $24 \mathrm{~h}$ & 850 & 850 & 845 & 843 & 862 & 5.0 & 6.1 & NS & NS \\
\hline $48 \mathrm{~h}$ & 877 & 882 & 875 & 876 & 887 & 4.4 & 5.3 & NS & NS \\
\hline \multicolumn{10}{|c|}{$\mathrm{N}$-free Om } \\
\hline $12 \mathrm{~h}$ & 351 & 382 & 398 & 345 & 357 & 16.5 & 20.2 & NS & NS \\
\hline $24 \mathrm{~h}$ & 545 & 550 & 568 & 546 & 529 & 10.0 & 12.3 & NS & NS \\
\hline $48 \mathrm{~h}$ & 664 & 670 & 684 & 663 & 649 & 5.0 & 6.1 & NS & $* * *$ \\
\hline \multicolumn{10}{|c|}{ Resid. fract. ${ }^{2}$} \\
\hline $12 \mathrm{~h}$ & 268 & 302 & 320 & 260 & 274 & 18.7 & 22.9 & NS & NS \\
\hline $24 \mathrm{~h}$ & 486 & 492 & 517 & 487 & 468 & 11.2 & 13.8 & NS & NS \\
\hline $48 \mathrm{~h}$ & 617 & 627 & 643 & 620 & 604 & 5.6 & 6.9 & NS & $* *$ \\
\hline
\end{tabular}

$\mathrm{S}=$ sugar; $\mathrm{L}=$ level; ' Linear trend of sugar level, no significant quadratic trend; ${ }^{2} \mathrm{OM}$ minus crude protein, sugars and fermentation acids. 
content of NDF (582 g/ $\mathrm{kg} \mathrm{DM}$ ), and thus changes in degradation of the residual fraction may reflect changes in NDF degradation. No significant differences between the sugars were found, although disappearances of OM and $\mathrm{N}$-free $\mathrm{OM}$ were marginally higher with the xylose infusion. The ' $0 \mathrm{~h}$ wash' value (mg/ g) was 186 for $\mathrm{OM}, 512$ for $\mathrm{N} 122$ for $\mathrm{N}$-free OM 122 and 4 for the residual fraction.

The average disappearance of straw DM was $6.1 \%$ lower for the high level of sugar than for the basal diet after incubations of 24 and $48 \mathrm{~h}$.

\section{Rumen fermentation}

Mean values of rumen $\mathrm{pH}$, concentrations of ammonia $\mathrm{N}$ and total VFA and the molar proportions of individual fatty acids are given in Table 7. Rumen ammonia $\mathrm{N}$ concentration and molar proportion of isovalerate were markedly reduced when the amount of sugar in the basal diet was increased. There were significant linear $(\mathrm{P}<0.001)$ and quadratic $(\mathrm{P}<0.05)$ trends. The effect of sugar level on the molar proportion of valerate was significantly linear $(\mathrm{P}<0.05)$ and quadratic

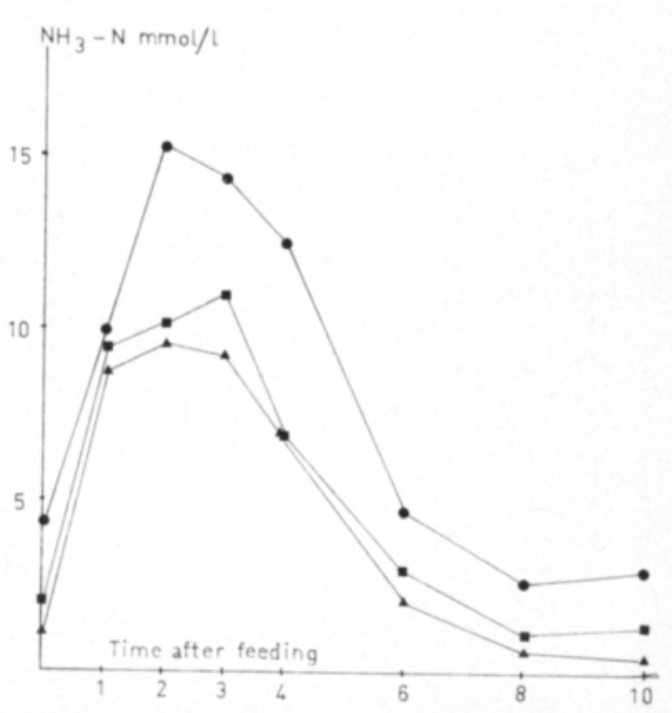

Fig. 1. The effect of sugar infusions on rumen ammonia cuncentration in cattle given diets of grass cilage and barley (๑ $0 \mathrm{~g} / \mathrm{d} ; \square 450 \mathrm{~g} / \mathrm{d}$; A $900 \mathrm{~g} / \mathrm{d})$. 

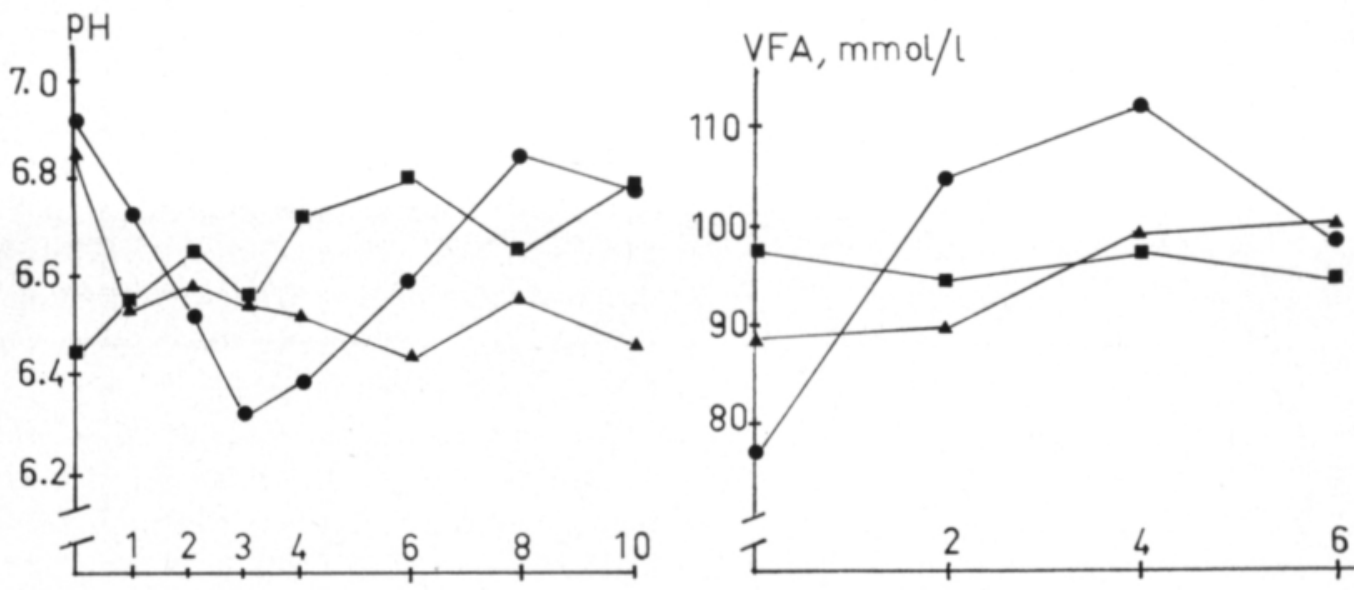

Acetic acid

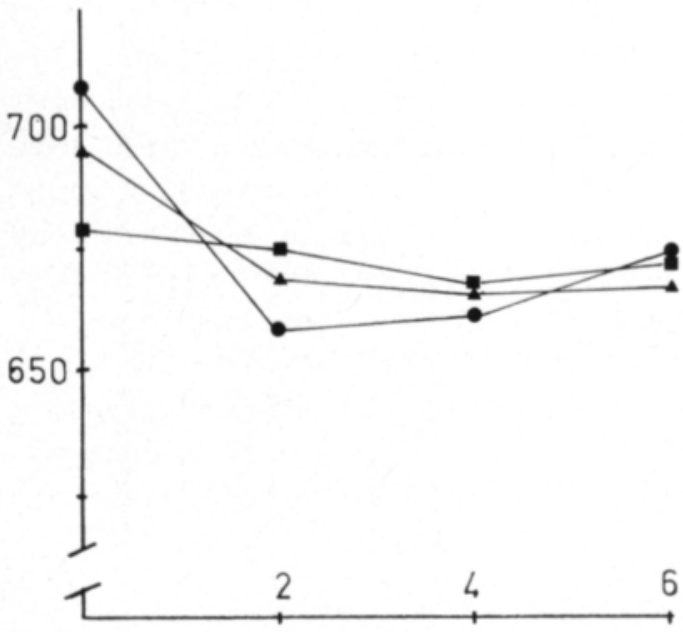

Propionic acid

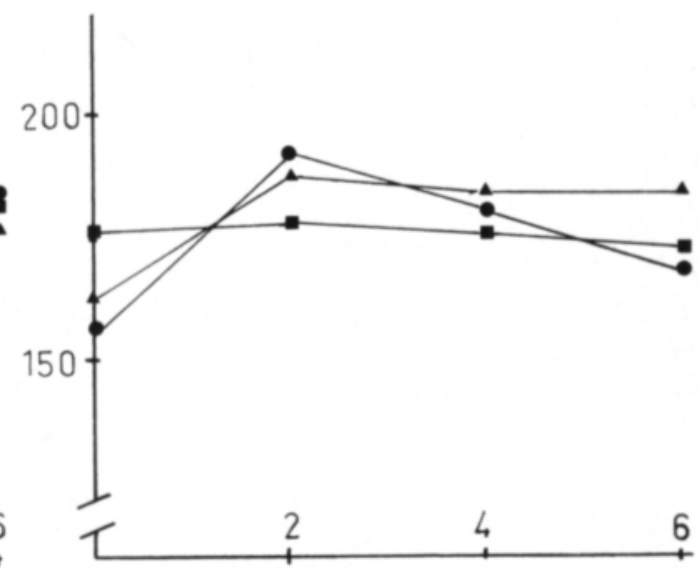

Isovaleric acid
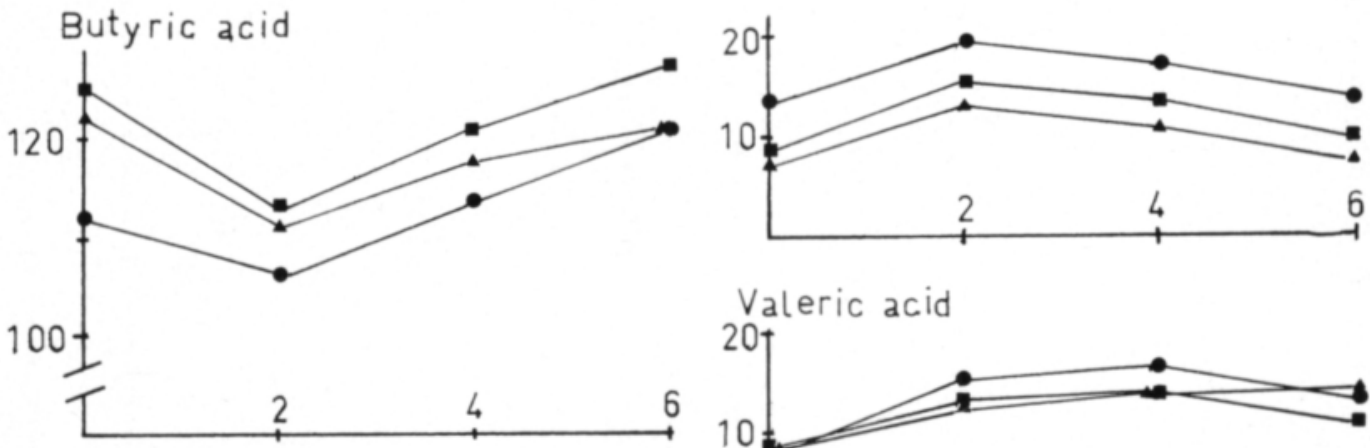

Valeric acid

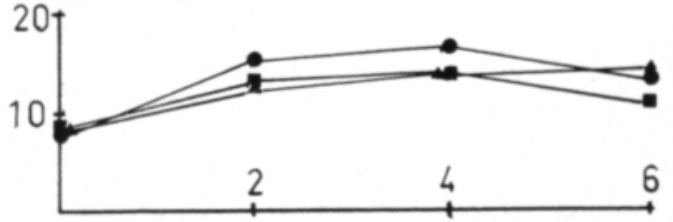

Fig. 2. The effect of sugar infusions on rumen $\mathrm{pH}$, total VFA and the proportions of individual fatty acids in cattle given diets of grass silage and barley $(0 \mathrm{~g} / \mathrm{d} ; \mathbf{0} 450 \mathrm{~g} / \mathrm{d} ; \boldsymbol{\Lambda} 900 \mathrm{~g} / \mathrm{d})$. 
$(\mathrm{P}<0.05)$. Sucrose infusion resulted in slightly, although significantly $(\mathrm{P}<0.05)$, lower ammonia concentration than did xylose.

Concentration of total VFA and the molar proportions of acetate, propionate and butyrate were not affected by the level of sugar infusion. As compared to sucrose infusion, xylose infusion showed a significant $(\mathrm{P}<0.05)$ increase in the proportion of acetate and an associated decrease $(\mathrm{P}<0.01)$ in that of butyrate without any effect on the proportion of propionate.

With the sugar infusions, rumen ammonia concentration was below $3 \mathrm{mM}$ before feeding and again fell below this level $6 \mathrm{~h}$ post-feeding (Fig. 1). The postprandial changes in ammonia $\mathrm{N}$ concentration were significantly $(\mathrm{P}<0.01)$ different between the basal diet and diets with sugar infusions.

Postprandial changes in rumen $\mathrm{pH}$, the concentration of total VFA and the proportions of most of the individual fatty acids were smaller in the case of sugar infusions (Fig. 2). Interaction between the level of sugar infusion and sampling time was significant as regards $\mathrm{pH}(\mathrm{P}<0.001)$, total VFA $(\mathrm{P}<0.01)$, and the proportions of acetate $(\mathrm{P}<0.01)$, propionate $(\mathrm{P}<0.01)$ and valerate $(\mathrm{P}<0.05)$. The most pronounced differences between the basal diet and sugar infusions in the postprandial changes in rumen fermentation characteristics were in the quadratic effect of sampling time. No interactions between the type of sugar and sampling time were found.

\section{Discussion}

\section{OM digestion}

The average value of 0.694 obtained for digestible OM disappearing apparently in the rumen is in agreement with the value of 0.70 calculated by THOMAs and CHAmberlain (1982) for sheep given silage based diets. A slightly higher value of $0.73-0.75$ for cattle given silage diets was adopted from the literature by Agricultural Research Council (1984).
A similar small increase in the total OM digestibility of the diet was observed by ENGLAND and GiLl (1985) when increasing levels of sucrose supplements were given with silage to young cattle. The increased amount of faecal OM with sugar infusions consisted mainly of NDF. The amounts of faecal OM not analysed as NDF were 282, 287 and $329 \mathrm{~g} / \mathrm{d}$ for control, low and high sugar infusions, respectively. In vitro digestibility of silage $O M$ was $0.643,0.646$ and 0.650 when the sugar levels of 0,450 and $900 \mathrm{~g} / \mathrm{d}$ were infused and therefore, it can be assumed that the results were not affected by the variation in silage digestibility. Further, similar or higher increases in the output of faecal OM with increasing addition of sugar were obtained when CoEDTA or acid insoluble ash (VAn Keulen and Young 1977) was used as indigestible marker.

Similar values as in the present study for the proportion of $\mathrm{OM}$ entering the duodenum that disappeared in the intestines can be calculated from the results of Тномаs et al. (1980b) and ROOKE et al. (1985b) for sheep and cattle given silage diets. The increased amount of OM digested in the intestines when sugar was infused can be attributed in part to increased synthesis of microbial matter in the rumen and its subsequent digestion and in part to increased digestion of NDF in the lower tract.

\section{$N$ metabolism}

The lower ammonia concentration in the rumen with sugar infusions is consistent with earlier observations of SYRJÄLÄ (1972) and Chamberlain et al. (1985). The effect of sugar level on the ammonia concentration was curvlinear. In contrast to the findings of Chamberlain et al. (1985), sucrose infusion here produced a larger reduction in rumen ammonia concentration than did xylose. This discrepancy may be related to the different method by which the sugars were incorporated in the ration: Chamberlain et al. gave the sugars via the rumen cannula at feeding time. The higher fermentation rate of sucrose than 
of xylose (SuTton 1968) causes a larger reduction in rumen $\mathrm{pH}$ and higher ammonia concentration, and they concluded that the different action of the sugars may in part be associated with this reduction of rumen $\mathrm{pH}$. In the present study, continuous infusion of the sugars did not reduce rumen $\mathrm{pH}$ below 6.4 with sucrose or xylose (Fig. 2).

Relative to the basal diet of silage and barley sugar infusions increased markedly production of microbial protein. Efficiency of microbial protein synthesis has been found lower in animals given silage diets than in those given hay, as summarized by Tномаs (1982) and Agricultural Research Council (1984). One probable reason for the lower efficiency with silage diets is that silage OM consists of fermentation products and the yield of ATP $/ \mathrm{kg}$ OMADR is low. Another reason may be that the rates of ammonia and energy release are poorly matched in silage. In the present study, the silage was not extensively fermented and had a low concentration of fermentation acids and low proportion of ammonia and soluble $\mathrm{N}$ in total $\mathrm{N}$.

The positive effect of sugar infusion on microbial $\mathrm{N}$ production in the rumen indicates that microbial synthesis was limited by energy supply even with silage of good fermentation

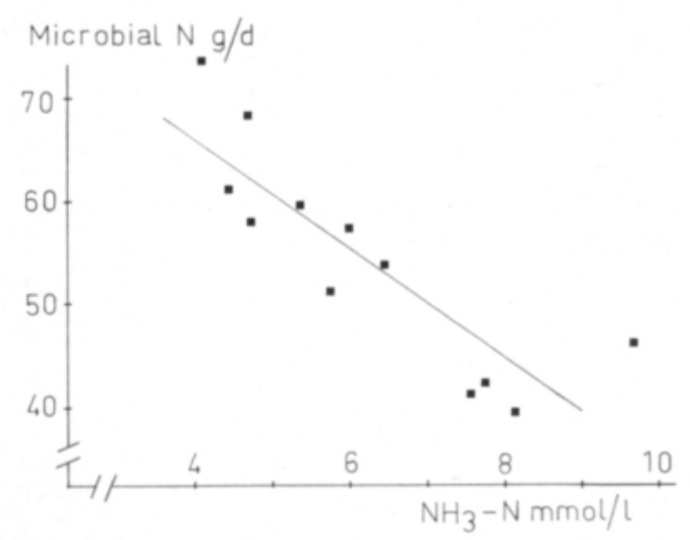

Fig. 3. The relation of rumen ammonia concentration and duodenal flow of microbial $\mathrm{N}$ in cattle given diets of grass silage and barley supplemented with intraruminal infusions of sugars. $y=88$ $( \pm 6.7)-3.86( \pm 0.74) \times$; $12 ; r 0.856$; $\mathrm{P}<0.001)$. characteristics and supplemented with barley. Changes in rumen ammonia concentration reflected well differences in the net incorporation of ammonia by the rumen microbes (Fig. 3). Slightly lower production of microbial $\mathrm{N}$ with xylose is consistent with the higher ammonia concentration when xylose infusion was given. It is likely that the effect of the sugars on microbial synthesis was related to energy supply per se rather than to the synchronization of ammonia production and energy release as was proposed by SYRJÄLÄ (1972). The release of ammonia from silage $\mathrm{N}$ compounds was rapid (Fig. 1), but continuous infusion of sugars supported an even supply of energy during the whole feeding cycle. Supporting evidence against the synchoronization theory is provided by CHAMBERLAIN et al. (1985) who found a considerable influence on the time-course carbohydrate fermentation but no influence on the rumen ammonia concentration when barley supplements were fed $2 \mathrm{~h}$ before, $1 \mathrm{~h}$ before and at the same time as silage.

The method by which the sugars are given may have some effect on microbial synthesis. Large amounts of sugars given in a single meal cause a rapid reduction in rumen $\mathrm{pH}$. RuSSEL and Dombrowski (1980) found in continuous culture that growth yields of most bacteria were depressed at $\mathrm{pH}$ values lower than 6.0, cellulolytic bacteria being the most sensitive. The advantage of an even supply of energy for microbial synthesis has been demonstrated with continuous feeding and increased feeding frequency in sheep (Al AtTAR et al. 1976) and in dairy cows (TAMmINGA 1979).

Low ammonia concentration $(0.5-3.0 \mathrm{mM})$ with sugar infusions $6-12 \mathrm{~h}$ after feeding did not seem to limit microbial synthesis. Such a low concentration of ammonia $\mathrm{N}$ in the rumen of cattle fed silage diets has been previously noted by RoOKE et al. (1985b) and THOMSON et al. (1981). There has been considerable controversy over the optimum ammonia concentration to sustain maximum microbial yields. Satter and Slyter (1974) found 1.4-3.6 $\mathrm{mM}$ to be adequate for maximum 
growth of rumen micro-organisms in vitro, and the general conclusion is that $3.5 \mathrm{mM}$ is adequate with normal forage concentrate diets (Miller 1982). A mean ammonia concentration of $3.5 \mathrm{mM}$ will assure the bacteria enough ammonia even during the low point of the ammonia concentration cycle (SATTER 1982). Many rumen bacteria have a very high affinity for ammonia, and these organisms can attain $95 \%$ of their maximal growth rate in the presence of even $1.0 \mathrm{mM}$ ammonia (SCHAEFER et al. 1980).

Of the individual fatty acids, only the molar proportion of isovalerate showed a significant correlation $\left(r-0.88^{* * *}\right)$ with the amount of microbial $\mathrm{N}$ produced. Examination of the biochemical pathways concerned shows that the amount of ATP generated per mole of hexose fermented in the rumen is not markedly influenced by the VFA pattern produced (TAmminga 1979; Czerkawski 1986). Branchedchain volatile fatty acids are required for the biosynthesis of branched-chain amino acids or higher fatty acids (ALLISON and BRYANT 1963). The lower proportion of isovalerate with sugar infusion indicates efficient incorporation of this acid by rumen microbes. The molar proportion of isovalerate was highly correlated

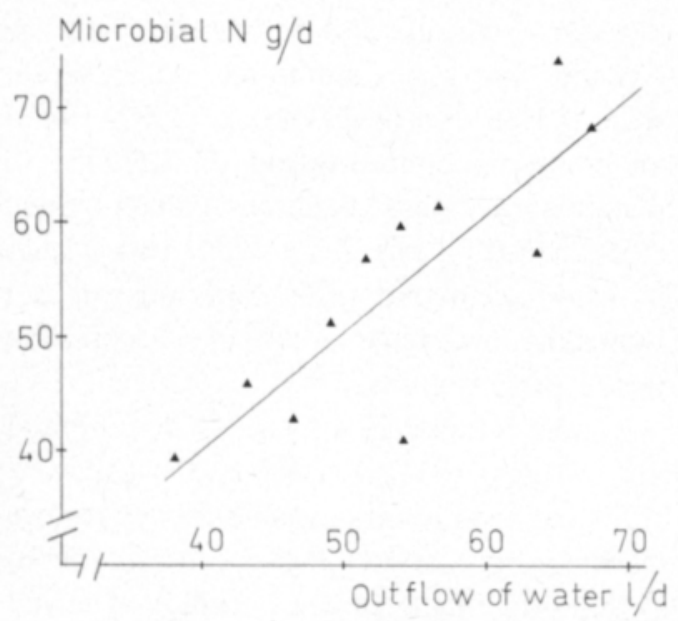

Fig. 4. The relation of duodenal flow of water and microbial $\mathrm{N}$ in cattle given diets of grass silage and barley supplemented with intraruminal infusions of sugars. $y=-1.1( \pm 11.8)+1.03$ $( \pm 0.20) \times$; $12 ; r 0.833 ; \mathrm{P}<0.001)$. with the ammonia concentration in the rumen ( $\left.r 0.91^{* * *}\right)$.

An increasing liquid phase dilution rate has been associated with an increase in the efficiency of microbial growth (HARRISON and Mcallan 1980). This is largely because the proportion of energy consumed for maintenance diminishes. The liquid dilution rate was not determined in the present study, but outflow of water at the duodenum was markedly increased by sugar infusions and the dilution rate was likely increased as well. There was a close linear relationship between the outflow of water and microbial N production (Fig. 4).

Most of the rumen bacteria are found to be associated with feed particles (HoBson and WALLACE 1982) and the rate of passage of feed particles may not always be related to liquid phase dilution (MATHERS and MiLler 1981). Soluble sugars were available in the liquid phase during the whole feeding cycle, which may change the ratio of attached to free bacteria. This shift would increase the dilution rate of microbes from the rumen because the dilution rate of liquid is normally higher than that of particles.

The depressive effect of sugar infusions on the apparent $\mathrm{N}$ digestibility is consistent with earlier experiments when sucrose (SYrJäLÄ 1972; ENGLAND and GiLl 1985) or starch (KAISER et al., 1983) supplements were given with grass silage. In contrast, GILl and UlyaTT (1977) did not observe any effect on $\mathrm{N}$ digestibility when a mixture of starch and sucrose was infused in the rumen of sheep given silage. The increased amount of $\mathrm{N}$ voided in the faeces when sugar was infused can partly be explained by the larger amount of indigestible residue of bacterial protein produced in the rumen. Another factor may be increased carbohydrate fermentation in the hindgut, leading to synthesis of microbial biomass there and its excretion in the faeces (ARMSTRONG and SMithard 1979).

\section{Fibre digestion}

Increase in the sugar level resulted in a significant reduction in the digestibility of 
fibre components and in the proportion of ruminal digestion. A reduction in fibre or cellulose digestibility has been noted in many studies (Thomas et al. 1980b; KAISER et al. 1983; EnGLAND and Gill 1985), following the supplementation of forages with readily fermentable carbohydrates. The proportion of digestible cellulose broken down in the rumen (0.93) agrees with the values reported by BeEver et al. (1977) and Thomas et al. (1980b), but lower values have been reported especially with pelleted forage (Тномson et al. 1972) or with high proportion of concentrate in the diet (Macrae and Armstrong 1969). The proportion of digestible hemicellulose disappearing in the rumen was similar to that of cellulose.

The increase in the postruminal digestion of cellulose and hemicellulose with sugar infusions was insufficient to compensate the reduced digestion in the rumen. The amount of NDF excreted in the faeces was increased by $0.16 \mathrm{~g} / \mathrm{g}$ sugar infused and that of ADF by $0.08 \mathrm{~g}$. Digesta retention time in caecum and colon is quite short; values of $5-10 \mathrm{~h}$ were obtained from direct measurements (Grovum and Williams 1977) or can be calculated from reciprocal of $k_{2}$ (HARTNELL and SATter 1979; Huhtanen 1987). Because of the short digesta retention time and quite small pool of digestible fibre entering the caecum, complete compensation of reduced fibre digestion in the rumen cannot be expected. Moreover, if fibre digestion in the hindgut is characterized by a similar lag time as in the rumen (MERTENS 1977), the amount of fibre digested postruminally would be expected to be further reduced.

The effect of sugar infusion on the disappearance of $\mathrm{OM}, \mathrm{N}$-free $\mathrm{OM}$ and the residual fraction from nylon bags incubated in the rumen was consistent with the in vivo digestibility of the various fibre components in the rumen and in the total tract. Correlation between the amount of the residual fraction disappearing in $24 \mathrm{~h}$ and in vivo NDF digestibility was $0.97^{* * *}(n 6)$. The adverse effect of the sugar infusions tended to be less severe in the case of disappearance from nylon bags than of in vivo digestion. DM intake was higher with the sugar supplements, which may have reduced digesta retention time in the rumen (Growum and Williams 1977) and thus contributed to fibre digestion. Calculation of degradation constants using the equations of ØrSKov and McDONALD (1979) and McDONALD (1981) shows the sugar infusions to have increased the lag time and indigestible fibre pool without any change in the rate of digestion. The lag time (h), potentially degradable pool $(\mathrm{mg} / \mathrm{g})$ and rate of digestion of $\mathrm{N}$-free $\mathrm{OM}$ were for the control diet 1.9, 720 and 0.062 and for sugar the infusions (mean value) $4.1,687$ and 0.066 , respectively. The increased lag time is in agreement with MERTEns and LOFTEn (1980) who noted, with starch supplement, an increased lag time of fibre digestion in vitro. However, in their study the potential extent and the rate of fibre digestion were not affected by starch addition.

The optimal ammonia concentration needed to support a maximal rate of fermentation may be higher than that suggested to be minimum for microbial growth. Mehrez et al. 1977) observed an increase in the rate of breakdown of barley until the ammonia concentration reached $17 \mathrm{mM}$, whereas ORTEGA et al. (1979) were unable to show any increase in the rate of fermentation by increasing the rumen ammonia concentration from 4.5 to $19.6 \mathrm{mM}$. ØRSKov (1982) found an ammonia concentration of $1.5 \mathrm{mM}$ to maximize the rate of digestion of alkali-treated straw. On the basis of the latter two studies it would seem that fibre digestion was not limited by low rumen ammonia concentration in the present study.

Rumen cellulolysis appears to be inhibited by low rumen $\mathrm{pH}$ (pH effect) and by the availability of readily fermentable carbohydrates (carbohydrate effect) (Mould et al. 1983). Cellulolysis in the rumen is inhibited at $\mathrm{pH}$ 6.0-6.2 (STEWART 1977; Mould and ØRSKOV 1983). RuSSEl and Dombrowski (1980) found the growth of pure cultures of cellulolytic bacteria to decrease sharply when the $\mathrm{pH}$ fell 
below about 6.3 . In the present study rumen $\mathrm{pH}$ was not affected by sugar infusion and was throughout the day above the critical values cited above. From this observation it can be concluded that the depression in fibre digestion was due to the availability of readily fermentable carbohydrates. This is in agreement with Mould et al. (1983), who found that reduction in DM degradation with molasses supplements could not be alleviated by increasing rumen $\mathrm{pH}$. El-Shazly et al. (1961) proposed that when readily fermentable carbohydrates are given, the competition for essential nutrients is increased. Cellulolytic microorganisms appear to be less competitive and unable to metabolise and reproduce at a rate fast enough to maintain themselves in the rumen, and the number of cellulolytic bacteria falls. According to a review by VAN GYLSWYK and SCHWARTZ (1984), on the other hand, the effect of readily fermentable carbohydrates on fibre digestion is generally not due to a decline in the number of cellulolytic bacteria. In the present study, the increased lag time of fibre digestion with sugar infusions indicates that rumen microbes preferentially utilize soluble carbohydrates before starting on the degradation of fibre (MERTENS 1977). With sugar infusions the fluid fraction contained approximately 0.60 of the total flow of microbial $\mathrm{N}$ from the rumen, while the corresponding value for the control diet was 0.49. A similar effect was observed in the ratio of RNA content in the whole digesta to RNA content in the solid phase. The ratio was 1.16 for control diet and 1.23 and 1.31 for low and high sugar infusion. These observations indicate a shift in the ratio of free bacteria to attached bacteria with sugar infusions which may in part explain reduced fibre digestibility.

\section{Rumen fermentation}

Continous infusion of sugars caused a stable fermentation with less diurnal variation in rumen $\mathrm{pH}$, total VFA and proportions of most individual fatty acids. As was found by Chamberlain et al. (1985) in vivo and Sutton (1968) in vitro, xylose increased the proportion of acetate and reduced that of butyrate. In contrast to the studies of ØrSKov and Oltuen (1967), Syrjälä (1972), and CAmberLAIN et al. (1985) sucrose did not increase the proportion of butyrate. The difference may be related to the method by which the sugars were given.

\section{Conclusions}

The present results indicate that production of microbial protein from silage nitrogen can be increased by the continuous supply of soluble carbohydrates. On silage diets the low production of microbial $\mathrm{N}$ seems to be limited by the energy supply per se rather than by the difference in the energy and nitrogen releases from silage. At the same time, a continuous supply of readily fermentable carbohydrates reduces fibre digestibility, although rumen $\mathrm{pH}$ is not affected. This would tend to reduce silage DM intake and, hence utilization of silage.

\section{Acknowledgements}

The author is grateful to Hannele AlaSeppälä and M. Ranta for technical assistance during the experiment and to veterinarians Leena Oksanen and K. Skutnabb for surgical preparations of the experimental animals.

\section{References}

Al Attar, A., Evans, R.A. \& Axford, R.F.E. 1976. The effect frequency of feeding and of dietary energy source upon microbial synthesis in the rumen of sheep. Proc. Nutr. Soc. 35: 109A.
Allison, M.J. \& Bryant, M.P. 1963. Biosynthesis of branched-chain amino acids from branched-chain fatty acids by rumen bacteria. Arch. Biochem. Biophys. 101: 269--277. 
Armstrong, D.G., Smithard, R.R. 1979. The fate of carbohydrate in the small and large intestine of the ruminant. Proc. Nutr. Soc. 38: 283-294.

Agricultural Research Council. 1984. The Nutrient Requirements of Ruminant Livestock Supplement 1. Slough: Commonwealth Agricultural Bureaux.

Beever, D.E., Thomson, D.J. Cammel, S.B. \& Harrison, D.G. 1977. The digestion by sheep of silages made with and without addition of formaldehyde. J. agric. Sci., Camb. 88: 61-70.

Chamberlain, D.G., Thomas, P.C. \& Wait, M.K. 1982. The rate of addition of formic acid to grass at ensilage and the subsequent digestion of the silage in the rumen and intestines of sheep. Grass \& Forage Sci. 37: 159-164.

Chamberlain, D.G., Thomas, P.C., Wilson, W., Newbold, C.J. \& Macdonald, J.C. 1985. The effects of carbohydrate supplements on ruminal concentration of ammonia in animals given grass silage. J. agric. Sci., Camb. 104: 331-340.

Czerkawskı, J.W. 1986. An introduction to rumen studies. 236 p. Pergamon Press: Oxford.

El-Shazly, K., Dehority, B.A. \& Johnson, R.R. 1961. Effect of starch on the digestion of cellulose in vitro and in vivo by rumen microorganisms. J. Anim. Sci. 20: $268-273$.

EnGland, P. \& Gill, M. 1985. The effect of fish meal and sucrose supplementation on the voluntary intake of grass silage and live-weight gain of young cattle. Anim. Prod 40: 259-265.

FAICHNEY, G.H. 1975. The use of markers in partition digestion within gastrointestinal tract of ruminants. In Digestion and Metabolism in The Ruminant (ed. I.W. McDonald and A.C.I. Warner) pp. 277-291. Armidale, N.S.W.: University of New England.

France, J. \& Siddons, R.C. 1986. Determination of digesta flow by continuous marker infusion. J. theor. Biol. 121: 105-119.

Gill, M. \& Ulyatt, M.J. 1977. The effect of supplementation with protein, energy and L-methionine, on the digestion of silage by sheep. J. agric. Sci., Camb 89 : $43-51$.

Goering, H.R. \& VAn Soest, P.J. 1970. Forage fiber analyses. Agriculture Handbook No. 379. United States Department of Agriculture. Washington.

Grovum, W.L. \& Williams, V.J. 1977. Rate of passage of digesta in sheep. 6. The effect of level of food intake on mathematical predictions of the kinetics of digesta in the reticulorumen and intestines. $\mathrm{Br}$. J. Nutr. 38: $425-436$.

Harrison, D.G. \& Mcallan, A.B. 1980. Factors affecting microbial growth yields in the reticulo-rumen. In Digestion Physiology and Metabolism in Ruminants (ed. Y. Ruckebusch \& P. Thivend) pp. 205-226. Lancaster: MTP Press Ltd.

Hartnell, G.F. \& Satter, L.D. 1979. Determination of rumen fill, retention time and ruminal turnover rates of ingesta at different stages of lactation of dairy cows. J. Anim. Sci. 48: 381-392.

Hobson, P.N. \& Wallace, R.J. 1982. Microbial ecology and activities in the rumen. Part I. CRC Critical Reviews in Microbiology 9: 165-225.

HuIDA, L. 1973. Quantitative determination of volatile fatty acids by gasliquid chromatography. J. Agric. Soc. Finl. 45: 483-488.

Huhtanen, P. 1987. The effect of dietary inclusion of barley, unmolassed sugar beet pulp and molasses on milk production, digestibility and digesta passage in dairy cows given silage based diet. J. Agric. Sci. Finl. 59: $101-120$.

Kaiser, A.G., Osbourn, D.F. \& England, P. 1983. Intake, digestion and nitrogen retention by calves given ryegrass silages: influence of formaldehyde treatment and supplementation with maize starch or maize starch and urea. J. agric. Sci., Camb. 100: 63-74.

Kelly, N.C. \& Thomas, P.C. 1978. The nutritive value of silages. Energy metabolism in sheep receiving diets of grass silage or grass silage and hay. Br. J. Nutr. 40: 205-219.

Macrae, J.C. \& Armstrong, D.G. 1969. Studies on intestinal digestion in the sheep. 2. Digestion of some carbohydrate constituents in hay, cereal and hay-cereal rations. Br. J. Nutr. 23: 377-387.

Mathers, J.C. \& Miller, E.L. 1981. Quantitative studies of food protein degradation and the energetic efficiency of microbial protein synthesis in the rumen of sheep given chopped lucerne and rolled barley. $\mathrm{Br}$. J. Nutr. 45: $587-604$.

Mccullough, H. 1967. The determination of ammonia of in whole blood by direct colorimetric method. Clinica Chimica Acta 17: 297-309.

MCDONALD, I. 1981. A revised model for the estimation of protein degradability in the rumen. J. agric. Sci., Camb. 96: 251-252.

MCDOnald, P. 1982. The effect of conservation processes on the nitrogenous components of forages. In Forage Protein in Ruminant Animal Production (ed. D.J. Thomson, D.E. Beever and R.G. Gunn) pp. 41-49. Occasional Publication of the British Society of Anim. Prod. No. 6.

Mehrez, J.R., Ørskov, E.R. \& Mcdonald, I. 1977. Rates of rumen fermentation in relation to ammonia concentration. Br. J. Nutr. 38: 437-443.

Mertens, D.R. 1977. Dietary fiber components: relationship to the rate and extent of ruminal digestion. Fed. Proc. 36: 187-192.

Mertens, D.R. \& Loften, J.R. 1980. The effect of starch on forage fiber digestion kinetics in vitro. J. Dairy Sci. 63: $1437-1446$.

Miller, E.L. 1982. The nitrogen needs of ruminants. In Forage Protein in Ruminant Animal Production (ed. D.J. Thomson, D.E. Beever and R.G. Gunn) pp. 79-87. Occasional Publication of the British Society of Anim. Prod. No. 6. 
Mould, F.L. \& Ørskov, E.R. 1983. Manipulation of rumen fluid $\mathrm{pH}$ and its influence on cellulolysis in sacco, dry matter degradation and the rumen microflora of sheep offered either hay or concentrate. Anim. Feed Sci. Technol. 10: 1-14.

Mould, F.L., Ørskov, E.R. \& Mann, S.O. 1983. Associative effects of mixed feed. I. Effects of type and level of supplementation and the influence of the rumen fluid $\mathrm{pH}$ on cellulolysis in vivo and dry matter digestion of various roughages. Anim. Feed Sci. Technol. 10: 15-30.

Ørskov, E.R. 1982. Protein nutrition in ruminants. London. Academic Press.

Ørskov, E.R. \& OLtJen, R.R. 1967. Influence of carbohydrate and nitrogen sources on the rumen volatile fatty acids and ethanol of cattle fed purified diets. J. Nutr. 93: $222-228$.

Ørskov, E.R. \& Mcdonald, I. 1979. The estimation of protein degradability in the rumen from incubation measurements weighted according to the rate of passage. J. agric. Sci., Camb. 92: 499-503.

Ørskov, E.R. \& Macleod, N.A. 1983. Flow of endogenous $\mathrm{N}$ from the rumen and abomasum of cattle given protein-free nutrients. Proc. Nutr. Soc. 42: 61A.

Ortega, M.E., Stern, M.D. \& Satter, L.D. 1979. The effect of rumen ammonia concentration on dry matter disappearance in situ. J. Dairy Sci. 62. Suppl. 1: 76 (abstract).

Porter, M.G., Patterson, D.C., Steen, R.W. \& Gordon, F.J. 1984. Determination of dry matter and gross energy of grass silage. Proceedings of the 7th Silage Conference (ed. F.J. Gordon and E.F. Unsworth) pp. 89-90. Queen's Univ. Belfast.

Robertson, J.B. \& VAn Soest, P.J. 1977. Dietary fiber estimation in concentrate feedstuffs. 69th Meeting of American Society of Animal Science No. 639.

Rooke, J.A., Brett, P.A., Overend, M.A. \& Armstrong, D.G. 1985a. The energetic efficiency of rumen microbial synthesis in cattle given silage-based diets. Anim. Feed Sci. Technol. 13: 255-267.

Rooke, J.A., Greife, H.A. \& Armstrong, D.G. 1985 b. The digestion by cattle of silage containing diets fed at two dry matter intakes. 1. Digestion of organic matter a continuous culture. Br. J. Nutr. 53: 691-708.

SAtTER, L.D. 1982. A metabolizable protein system keyed to ruminal ammonia concentration - the Wisconsin System. In Protein Requirements for Cattle (ed. F.N. Owens) pp. 245-264. Oklahoma State University. MP-109.

SATter, L.D. \& Styter, L.L. 1974. Effect of ammonia concentration on rumen microbial protein production in vitro. Br. J. Nutr. 32: 199-208.

Schaefer, D.M., Davis, C.L. \& Bryant, M.P. 1980. Ammonia saturation constants for predominant species of rumen bacteria. J. Dairy Sci. 63: 1248-1263.

Snedecor, G.W. \& Cochran, W.C. 1967. Statistical methods. 6th edn. Iowa State University.
Stewart, C.S. 1977. Factors affecting cellulolytic activity of rumen contents. Appl. Environ. Microbiol. 33: $497-502$.

Sutton, J.D. 1968. The fermentation of soluble carbohydrates in rumen contents of cows fed diets containing large proportion of hay. Br. J. Nutr. 22: $689-712$.

SYrJĀLĀ, L. 1972. Effect of different sucrose, starch and cellulose supplements on the utilization of grass silage in ruminants. Ann. Acric. Fenn. 11: 199-276.

TAMmingA, S. 1979. Relation between different carbohydrates and microbial synthesis of protein. Instituut voor Veevoedingaonderzoek Hoorn. Report 130.

Tномаs, C. \& Tномаs, P.C. 1985. Factors affecting the nutritive value of grass silages. In Recent Advances in Animal Nutrition (ed. W. Haresign and D.J.A. Cole) pp. 223-256. London: Butterworths.

Tномаs, P.C. 1982. Utilization of conserved forages. In Forage Protein in Ruminant Animal Production (ed. D.J. Thomson, D.E. Beever and R.G. Gunn) pp. 67-76. Occasional Publication of the British Society of Anim. Prod. No. 6.

Thomas, P.C. \& Chamberlain, D.G. 1982. Silage as a foodstuff. In Silage for Milk Production (ed. J.A.F. Rook and P.C. Thomas) pp. 63-101. National Research Institute for Research in Dairying, Reading/Hannah Research Institute, Ayr.

Thomas, P.C., Chamberlain, D.G., Kelly, N.C. \& WAIT, M.K. 1980a. The nutritive value of silages. Digestion of nitrogenous constituents in sheep receiving diets of grass silage and grass silage and barley. $\mathrm{Br}$. $\mathrm{J}$. Nutr. 43: 469-479.

Thomas, P.C., Kelly, N.C., Chamberlain, D.G. \& WAIT, M.K. 1980b. The nutritive value of silage. Digestion of organic matter, gross energy and carbohydrate constituents in the rumen and intestines of sheep receiving diets of grass silage or grass silage and barley. Br. J. Nutr. 43: 481-489.

Thomson, D.J. 1968. The digestibility and utilization of fresh grass, hay and silage by sheep. Anim. Prod 10: 240. (abstract).

Thomson, D.J., Beever, D.E., Coelho da Silva, J.F. \& Armstrong, D.G. 1972. The effect in sheep of physical form on the sites of digestion of a dried lucerne diet. 1. Sites of organic matter, energy and carbohydrate digestion. Br. J. Nutr. 28: 31-41.

Thomson, D.J., Beever, D.E., Lonsdale, C.R., Haines, M.J. Cammel, S.B. \& Austin, A.R. 1981. The digestion by cattle of grass silage made with formic acid and formic acid-formaldehyde. Br. J. Nutr. 46: 193-207.

Tilley, J.M.A. \& Terry, R.A. 1963. A two-stage technique for in vitro digestion of forage crops. J. Br. Grassl. Soc. 18: 104-111.

Udén, P., Colucci, P.E. \& Van Soest, P.J. 1980. Investigation of chromium, cerium and cobalt as markers in digesta. Rate of passage studies. J. Sci. Food and Agric. 31: 625-632. 
Van Gylswyk, N.O. \& Schwartz, H.M. 1984. Microbial ecology of the rumen of animals fed high-fibre diets. In Herbivore Nutrition in Tropics and Subtropics (ed. F.M.C. Gilchirst and R.I. Mackie) pp. 359-377. Graighall: The Science Press.

Van Keulen, J. \& Young, B.A. 1977. Evaluation of acidinsoluble ash as a natural marker for digestibility studies. J. Anim. Sci. 44: 282-287.

Willams, C.H., David, D.J., RusmaA, O. 1962. The determination of chromic oxide in faeces samples by atomic absorption spectrometry. J. agric. Sci., Camb.
59: $381-385$.

ZINN, R.A. \& OwEns, F.N. 1982. Rapid procedure for quantifying nucleic acid content of digesta. In Protein Requirements for Cattle (ed. F.N. Owens) pp. 26-30. Oklahoma State University. MP-109.

ZinN, R.A. \& OWEns, F.N. 1986. A rapid procedure for purine measurement and its use for estimating net ruminal protein synthesis. Can. J. Anim. Sci. 66: $157-166$.

Ms received October 9, 1987

\section{SELOSTUS}

\section{Sakkarosi- ja xyloosi-infuusion vaikutus typen ja kuidun sulatukseen säilörehu-ohraruokinnalla}

\section{Pekka Huhtanen}

Koe-elāimină oli kaksi pötsi- ja ohutsuolifistelöityă aysonnia (elopaino $240 \mathrm{~kg}$ ). Perusruokintana oli $12 \mathrm{~kg}$ nurmisäilörehua ( $227 \mathrm{~g} \mathrm{ka} / \mathrm{kg}$ ja $25.7 \mathrm{~g} \mathrm{~N} / \mathrm{kg} \mathrm{ka}), 1$ kg litistettyă ohraa ja $100 \mathrm{~g}$ kivennäisseosta. Perusdieetin lisăksi sonnit saivat jatkuvana infuusiona pötsiin 0,450 ja $900 \mathrm{~g} / \mathrm{pv}$ joko sakkaroosia tai xyloosia.

Sokeriannosta lisăttäessä orgaanisen aineen (OA) virtaus ohutsuolen alkuosaan sekä sonnassa eritetyn $\mathrm{OA}: \mathrm{n}$ maaără lisääntyivät lineaarisesti $(\mathrm{P}<0.001) ; \mathrm{P}<0.01)$. Pötsissä sulatetun OA:n osuus oli keskimaaarin 0.694 , eikả sokereiden tai sokeritasojen vălillă ollut merkitseviả eroja.

Pötsinesteen $\mathrm{NH}_{3}$ - $\mathrm{N}$-pitoisuus ja isovaleriaanahapon osuus laskivat $(\mathrm{P}<0.001)$ sokeriannoksen kasvaessa. Sakkaroosi laski pötsinesteen $\mathrm{NH}_{3}-\mathrm{N}$-pitoisuutta enemmän $(\mathrm{P}<0.05)$ kuin xyloosi. Sokeritaso ei vaikuttanut etikka- propioni- ja voihapon osuuksiin pötsinesteen VFA:sta, mutta sakkaroosia infusoitaessa etikkahapon osuus oli pienempi $(\mathrm{P}<0.05)$ ja voihapon osuus suurempi $(\mathrm{P}<0.01)$ kuin xyloosia infusoitaessa.

Perusdieetillă ohutsuoleen virtaavan typen määrä oli $11.6 \mathrm{~g} / \mathrm{pv}$ pienempi kuin rehussa saadun typen määrä, mutta ylitti rehussa saadun typen määrän $21.6 \mathrm{~g} / \mathrm{pv}$ in- fusoitaessa pötsiin sokeria $900 \mathrm{~g} / \mathrm{pv}$. Mikrobitypen virtaus ohutsuoleen lisaaantyi lineaarisesti $(\mathrm{P}<0.001)$ sokeritason lisaaăntyessä. Merkkiaineena käytettiin nukleiinihappojen puriiniemäksiä. Mikrobisynteesin tehokkuus ( $\mathrm{g} \mathrm{N} / \mathrm{kg}$ pötsissă näennäisesti fermentoitunut $\mathrm{OA}$ ) oli 24.0, 29.1 ja 30.0 sokeritasoilla 0,450 ja $900 \mathrm{~g} / \mathrm{pv}$, vastaavasti. Pötsissă tuotetun mikrobitypen ja pötsinesteen $\mathrm{NH}_{3}$-N-pitoisuuden vălillă oli negatiivinen yhteys $(r=$ $-0.86 ; \mathrm{P}<0.001)$ sekă mikrobitypen ja nestevirtauksen ohutsuolessa vălillä positiivinen yhteys $(r=0.83$; $\mathrm{P}<0.001)$.

Neutraalidetergenttikuidun (NDF) ja happodetergenttikuidun $(\mathrm{ADF})$ virtaus ohutsuoleen $(\mathrm{P}<0.01$; $\mathrm{P}<$ $0.001)$ sekă eritys sonnassa $(\mathrm{P}<0.05)$ lisaaantyivăt lineaarisesti sokeriannosta lisättäessä. Sokereita infusoitaessa kuidun sulatus paksusuolessa lisaaăntyi, mutta tămă ei riittänyt kompensoimaan huonontunutta kuidun sulatusta pötsissä ja siten NDF:n ja ADF:n kokonaissulavuus oli huonompi $(\mathrm{P}<0.05)$. Sokeriannoksen vaikutus nailonpussimenetelmällä määritettyyn typettömăn orgaanisen aineen hăvikkiin oli yhdenmukainen huonontuneen kuidun in vivo -sulavuuden kanssa, joskin vaikutus oli pienempi nailonpussimenetelmällă mäăritettăessă. 